\title{
Joint Acoustic and Electrical Measurements for Unfrozen Water Saturation of Frozen
} Saline Soil

Lyu, Chuangxin ; Ingeman-Nielsen, Thomas; Amiri, Seyed Ali Ghoreishian ; Eiksund, Gudmund Reidar ; Grimstad, Gustav

Link to article, DOI:

10.5194/egusphere-egu2020-10334

Publication date:

2020

Document Version

Publisher's PDF, also known as Version of record

Link back to DTU Orbit

Citation (APA):

Lyu, C., Ingeman-Nielsen, T., Amiri, S. A. G., Eiksund, G. R., \& Grimstad, G. (2020). Joint Acoustic and Electrical Measurements for Unfrozen Water Saturation of Frozen Saline Soil. Abstract from EGU General Assembly 2020. https://doi.org/10.5194/egusphere-egu2020-10334

\section{General rights}

Copyright and moral rights for the publications made accessible in the public portal are retained by the authors and/or other copyright owners and it is a condition of accessing publications that users recognise and abide by the legal requirements associated with these rights.

- Users may download and print one copy of any publication from the public portal for the purpose of private study or research.

- You may not further distribute the material or use it for any profit-making activity or commercial gain

- You may freely distribute the URL identifying the publication in the public portal 


\title{
EGU2020-10334
}

https://doi.org/10.5194/egusphere-egu2020-10334

EGU General Assembly 2020

(c) Author(s) 2020. This work is distributed under

the Creative Commons Attribution 4.0 License.

\section{Joint Acoustic and Electrical Measurements for Unfrozen Water Saturation of Frozen Saline Soil}

Chuangxin Lyu ${ }^{1}$, Thomas Ingeman-Nielsen ${ }^{2}$, Seyed Ali Ghoreishian Amiri', Gudmund Reidar Eiksund ${ }^{1}$, and Gustav Grimstad ${ }^{1}$

${ }^{1}$ NTNU, Department of civil and environmental engineering, Norway (chuangxin.lyu@ntnu.no)

${ }^{2}$ Department of Civil Engineering, Technical University of Denmark (DTU), 2800 Kgs. Lyngby Denmark

\begin{abstract}
The climate change has aroused great concern on the stability and durability of the infrastructure installed on permafrost, especially for frozen saline clay with a large amount of unfrozen water content at subzero temperature. The joint electrical resistivity and acoustic velocity measurements are conducted for frozen saline sand and onsøy clay with $50 \%$ clay content and 20 40 g/L salinity in order to determine the unfrozen water content. A systematic program of tests involves the saline sand with different salinity, natural onsøy clay with the variable of temperature and freezing-thawing cycles and reconstituted onsøy clay with distinctive density and salinity. The data analysis of measurement results in combination with previous joint measurements for frozen soil resolves the effect of temperature, salinity, soil type and freezing-thawing cycles on the acoustic and electrical properties. An increase of temperature, fine content and salinity results in a decrease of both acoustic velocity and electrical resistivity. Electrical resistivity is sensitive to salinity, while acoustic velocity changes substantially near thawing temperature. We also find that both natural and reconstituted clay with similar water content and salinity show quite different acoustic velocity and electrical resistivity, which indicates that ice crystal structures are distinctive between natural and reconstituted samples. Besides, P-wave velocity is much more sensitive to the fabric change or induced cracks than electrical resistance during freezing-thawing cycles. In the end, acoustic models like the weighted equation (Lee et al., 1996), Zimmerman and King's model (King et al., 1988) and BGTL (Lee, 2002) are applied to the UWS estimates based on P-wave velocity and electrical models like Archine's law are adopted based on electrical resistance. Both estimated UWS from different methods is not always consistent. The difference can be up to $20 \%$.
\end{abstract}

Keywords: Frozen Saline Clay, Acoustic Velocity, Electrical Resistance, Unfrozen Water Saturation

References:

King, M. S., Zimmerman, R. W., \& Corwin, R. F. (1988, May). Seismic and Electrical-Properties of

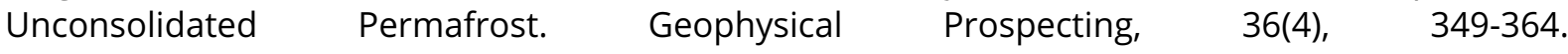
https://doi.org/10.1111/j.1365-2478.1988.tb02168.x

Lee, J. S. (2002). Biot-Gassmann theory for velocities of gas hydrate-bearing sediments. 
Lee, M. W., Hutchinson, D. R., Collett, T. S., \& Dillon, W. P. (1996). Seismic velocities for hydratebearing sediments using weighted equation. Journal of Geophysical Research: Solid Earth, 101(B9), 20347-20358. https://doi.org/10.1029/96jb01886 